What Lies Beneath?

The History of Underground

Public Conveniences in

Dunedin 1910-1929

ALISON BREESE

Turn-of-the-century public conveniences are more than just reminders of a now common public service. The early twentieth century saw enormous transformation in the approach to public conveniences in New Zealand, evident in the changing architectural approaches in their design, construction and visibility. They brought challenges to Dunedin and its local authority, Dunedin City Council. Tasked with their supply, the Council was required to not only invest heavily but also commit to this public provision. This article looks at the establishment and the reasons for the decline of the popularity and use of the underground conveniences. 
PUBLIC OPINION AND ABOVE GROUND CONVENIENCES

Nineteenth century residents and local authorities alike were concerned with the poor level of hygiene or outright filthiness in Dunedin. The new colonists feared that conditions could fall to the "Old World" standards and that Dunedin would duplicate the diseases and cramped conditions of 'Home". Dunedin slowly developed in the 1850 s, and the Dunedin Town Board (1855-1865) struggled to establish roading and sanitation infrastructure. Further to this the Otago goldrush hit in 1862, and the town expanded rapidly with an influx of people from all over the world. It took fourteen years after the first Europeans settled in Dunedin for the Board to erect Dunedin's first public convenience in $1862^{2}$. As the city grew from the success and wealth created by the goldrush, by the 1870 s Dunedin was the largest and wealthiest city in New Zealand. Over the next 45 years the city of Dunedin's population had grown to 36,068 , yet there were only ten conveniences across Dunedin. All ten were exclusively for male use.

Members of the public expressed their concern in the newspapers of the day. Topics included the lack of provision and the state of conveniences, with 'E.H' noting in 1900 that the "public urinals are a disgrace; very often over the boot tops in filthy water" 3 . These concerns were heightened in 1900 when a new wave of the bubonic plague began sweeping the globe.

Against this background, and to meet the ever-increasing demand, Dunedin City Council finally built four above ground urinals in 1904. All were in prominent public locations. The Council's efforts, however, caused even more complaints. One convenience in particular raised public ire: the Frederick Street iron convenience. The editor of the Otago Daily Times under the title "A Public Eyesore" opined that the Council should be beautifying the city but were doing the opposite by placing the unattractive structures in high profile areas ${ }^{4}$. G.L. Denniston led a deputation from neighbouring Knox Church urging the Council to remove the urinal, arguing that "It was an ugly building, it was a menace to traffic, and it was placed in a position where it could not fail to be offensive to the large number of women and children" 5 . S.M. Park from the Knox Church Deacon's Court believed it was in the interests of public morality and decency for it to be built elsewhere, away from the boys and girls who attended the Sunday School ${ }^{6}$. Park went on to suggest that if a convenience was needed in that location, it should

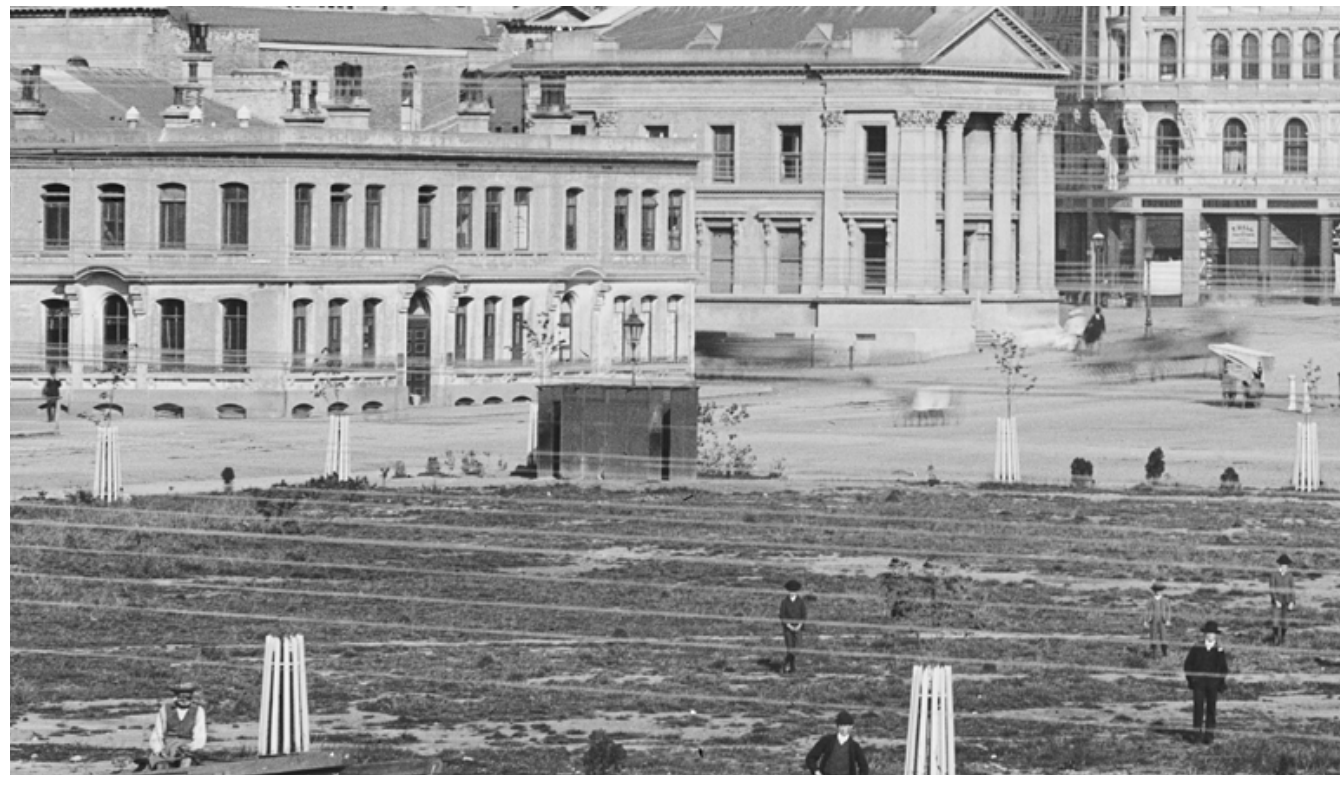

FIGURE 1. The Triangle (now Queens Gardens) 1879

showing a brick urinal, Te Papa Collections

In Victorian society, underground conveniences were favoured because they were 'hidden'. The European philosophy that all bodily activities should be removed from view was particularly influential and led to an international trend in underground facilities ${ }^{7}$. As is exemplified by Knox Church's Deacon's Court, Dunedin's Edwardian society was in accord with international trends. Public urination was indecent. The public toilet may be the only appropriate place for these bodily functions, but it was completely inappropriate to have situated near home or place of business ${ }^{8}$.

While numerous Council members were no doubt sympathetic to these arguments, the Council was limited in its ability to action the request for undergrounds. An iron above ground design cost $£ 70$; an underground convenience cost $£ 1500$. The difference was significant and fiscal realities imposed the economic above ground urinals on a reluctant community.

\section{THE UNDERGROUNDS PROPOSED}

In 1904, however, an important turning point in the public toilet discussion occurred when Richard Watkins Richards was appointed to the dual role of Town Clerk and City Engineer of the Dunedin City Council'.

Richards was born in Pembroke, Wales in 1863 and emigrated to Australia as a child. He was appointed City Surveyor 
for Sydney in 1887. In 1902 he left the Sydney City Council to work in private practice as a civil and consulting engineer. Two years later Richards took the appointment at Dunedin City Council in New Zealand ${ }^{10}$. Recently arrived from Sydney, he had seen the increasing importance authorities had placed on public health and sanitation in the wake of Australia's first bubonic outbreak. Indeed, Richards had been tasked with designing and building Sydney's first underground convenience in May 1901'11. In the Dunedin public sanitation debate then, Richards could speak from experience concerning the options for public conveniences for Dunedin ${ }^{12}$.

Richards opinions were recorded in the Dunedin City Council Departmental Reports of 1905-06. Richards urged the Council to consider underground conveniences. Sydney City Council had commissioned Richards to visit Europe in 1896 to report on various aspects of municipal government there and he noted that underground structures had displaced the "unsightly arrangements" of the above ground facilities. Using Birmingham's underground facilities as an example, he outlined the charging model which provided a continuous income after the initial outlay. Richards argued that Dunedin was well suited for the construction of the underground conveniences because of its many open spaces. $\mathrm{He}$ also argued that underground facilities would enable Dunedin to build a reputation as a well-kept, well-appointed modern city - an ideal many held as important ${ }^{13}$. Despite Richards' voice of reason, the Dunedin City Council took no action. This inaction saw the public increasingly voice their frustration about the conveniences in the local newspapers.

Despite his initial failure, Richards persisted with his argument. In 1907 he presented to the Dunedin City Council a comprehensive "voluminous" report, outlining and fully specifying the construction of modern underground conveniences ${ }^{14}$. With the Works Committee's support, the report was sent to Council. The Committee advised that "Council to be recommended to erect public conveniences for ladies and gentlemen at the Octagon; cost not to exceed $£ 1500$ ” 15

The report was discussed at length in the July 1907 Council meeting. Councillors were divided over the advantages of the underground options and the cost. The subterranean spaces were described in the newspaper as "superstructures" and had the cost to go with them ${ }^{16}$. Richards argued that underground conveniences were costly but could be more economically constructed than overseas ones. Dunedin could still maintain the high sanitary conditions and easy maintenance of similar international structures, while saving on construction costs.

The report was the final nail in the coffin of Counci opposition. In July 1907, the Council instructed Richards to begin preparing plans and specifications for two underground conveniences, working to a cost of around $£ 1500$. Only one month later, the Council voted to defer the works to the next year's financial allocations ${ }^{17}$.

Over the next year, debate continued to swirl around the lack and the state of the existing public toilets. One of the loudest debates centred on the lack of conveniences for women, which was common across the western world.

Dunedin City Councillor Keast reporting on a recent trip to Melbourne, stated that he was impressed by many things in the Australian city, but most particularly the underground conveniences provided for both sexes. He concluded that: "Some of the conveniences here would not be tolerated for a moment there" ${ }^{\prime 1}$. Councillor Barr leant his support after viewing Christchurch's underground conveniences. Built in 1907, the first in New Zealand, they were hidden at the rear of the Godley Statue in Cathedral Square, Barr found them 'admirable' in every way.

It was not until 1909 that a special fund was finally allocated by the Finance Committee to 'special works' for the city to the value of $£ 4795^{19}$. It was confirmed on 10 February 1909 that the fund was for the "execution of city works to be hereafter specified" ${ }^{20}$. With the financial resources guaranteed, the Dunedin City Council finally took the decision to build two underground conveniences in Dunedin. Most significantly, one would be erected for women ${ }^{21}$. Long overdue, the Council's decision was generally welcomed.

The first locations for underground conveniences were chosen because of their central position and, importantly, their potential to 'hide' the facilities ${ }^{22}$. The City Engineer was dispatched to inspect the two proposed sites for their suitability; the lower Octagon, near the Thomas Burns

Monument and the Custom House Square, under the Cargill's Monument. Equally important was space for the above ground shrubbery and rockeries, which played a large and important part in 'hiding' patrons from the public as they entered the facilities. The Engineer reported back to Council with positive reports that both sites would be suitable for what he saw as current and future use ${ }^{23}$. 
As well as being practically invisible, Dunedin's underground conveniences were designed to be aesthetically pleasing and state of the art. By the time of the death of King Edward VII in 1910, water closet and urinal styles had changed from the fancy decorative style of the Victorian age. Early twentieth century design brought a more austere, functional approach, and the elaborate ornamentation of the Victorian age had given way to plainer, more rounded designs. Water closets were now clean and uncluttered, and lavatories were more discreet on simple pedestals. There were practical reasons for this - it was easier to keep clean and less likely to get dirty.

Following international trends, Dunedin's new conveniences contained urinals and closets produced from the Twyford company: the No 7 'Adament' urinal range and the white closet 'Sentinel' washdown product ${ }^{24}$. The Twyford Company was among the first of the great sanitarians in England. They were contemporaries of George Jennings, who invented the first public flush toilets and designed the first underground public convenience, and Thomas Crapper, who founded a sanitary equipment company and invented the s-bend trap in 1880. Twyford's inventions were hailed as landmarks during the course of domestic sanitary reform ${ }^{25}$. Dunedin's new underground conveniences, again following international trends, were decorated in a simple colour palette. Most tiles were ordered in plain white and direct from 'Home'. The interiors in the underground facilities were fitted with wall to ceiling tiles for easy cleaning. Skirting and dados were enriched with cornice tiles. The Custom House Square convenience was more decorative than the Octagon facility, with an ornamental "Florite" frieze (possibly in coloured tiles) and dado.

The 'Adament' range of urinals were made from porcelain enamelled fireclay with an automatic flush cistern developed in 1889. These became extremely popular around the world. The large, hexagonal 'Adament' urinal could accommodate six in comfort, beneath a little tower, like a cupola, on top ${ }^{26}$. Dunedin did not have the hexagonal style, instead the 'Adament' urinals used in the Octagon undergrounds were built parallel against an exterior wall. The Custom House Square urinals had five urinals back to back with a more decorative top cupola.

Woodwork was also used to aesthetic effect. Cupboards and towel rollers were made from kauri and all the joinery work was completed in Tasmanian wood ${ }^{27}$. The seats in the attendant's spaces were also made from kauri and there

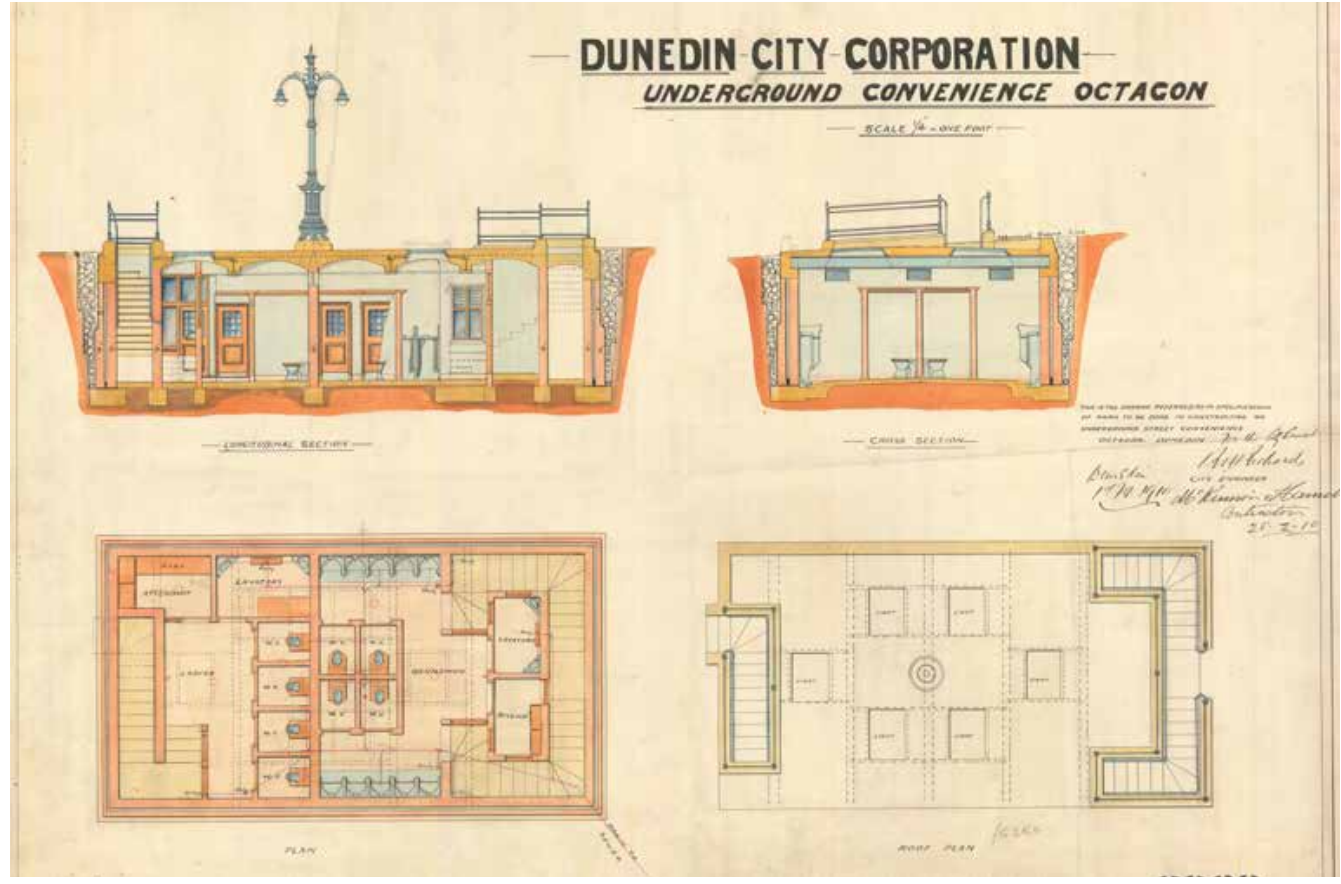

FIGURE 2. Octagon Underground Convenience Plans 1909, Plan 4427, City Engineers, DCC Archives

were brass coat and hat hooks, as well as electric heaters and looking glasses installed.

While these spaces were designed with modernity and privacy in mind, the challenges of being underground meant they had to be constructed to withstand their subterranean environment. The roof was designed to withstand the overhead traffic, and the walls and floors needed to be watertight to hold back the water table. Bitumen lined the walls to ensure they were waterproof ${ }^{28}$. Rainwater from the street above had to be stopped from running down the stairs. On occasions when the conveniences did flood, wate had to be pumped out ${ }^{29}$. Waterproofing efforts unfortunately proved less than successful: The Custom House Square underground conveniences suffered from leaks as soon as 1912, and the Octagon facilities had battled storm water leaks for some time before it was officially reported in March $1919^{30}$. As time went on the Octagon site continued to suffer numerous problems with leaks.

Ventilation was also very important in the subterranean spaces and the toilets had uptake ventilation pipes to the streets above. These were necessary fixtures but were also decorative with the cast iron bases of the ventilation pillars displaying ornamental patterns ${ }^{31}$. Ventilation in the Octagon undergrounds unfortunately proved ineffective and a fan and electric motor were installed in $1919^{32}$ 


\section{CONSTRUCTION BEGINS}

Contractors McKinnon and Hamilton won the tender for the Octagon men's and women's undergrounds with a price of $£ 1610$. The tender included the provision of ten urinals, four water closets and lavatory (hand basin) for gentlemen and four water closets and lavatory for women, with room for attendant accommodation ${ }^{34}$. The central location provided separate entrances for 'Ladies' and 'Gentlemen' down into the adjoining conveniences and both facilities had similar aesthetics ${ }^{35}$.

Mr A. Ferry, Roslyn, won the contract for the Custom House Square conveniences with the tender of $£ 1130$.

Designed for men only, the convenience was to include ten urinals, two water closets and lavatory with accommoda-

tion for an attendant. A later modification saw a wash basin built in lieu of a water closet $^{36}$. This convenience was $£ 480$ cheaper than the dual use Octagon convenience but was more decorative according to the specifications ${ }^{37}$.

With an estimated build time of six months, the Custom House Square undergrounds opened on time with little fanfare in the city on 8 November 1910. The Octagon undergrounds officially opened a few weeks later on 20 December $1910^{38}$.

The Finance Committee's 1909 special fund allowed for a third, and simpler, underground in London Street ${ }^{39}$. Built in 1910, the third convenience was located outside the Albert Arms Hotel. It was in a more prominent location, on the street corner of a busy intersection. The London Street underground convenience, designed for male use only, had no shrubbery nor any monuments to obscure it. Ferry again won the contract with a tender of $£ 56513 \mathrm{~s}^{40}$. The London Street convenience opened in 1911.

Despite the lack of fanfare, the public soon made their support of the underground facilities obvious. Within a few short weeks, the numbers availing themselves of the conveniences proved there was an enormous demand. Shortly after the Octagon and Custom House Square facilities opened, the numbers were tallied - the conveniences were used 42,720 times in the first four weeks. Dunedin's population at the time was $41,432^{41}$.

Within six months, the Custom House conveniences were

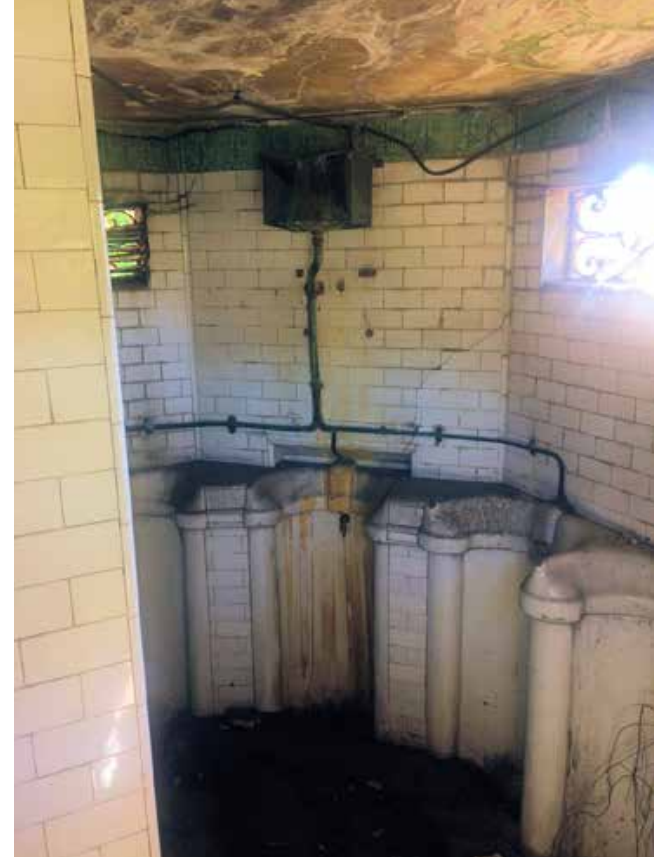

FIGURE 3. Manor Place urinals interior, taken 2017, Alison Breese

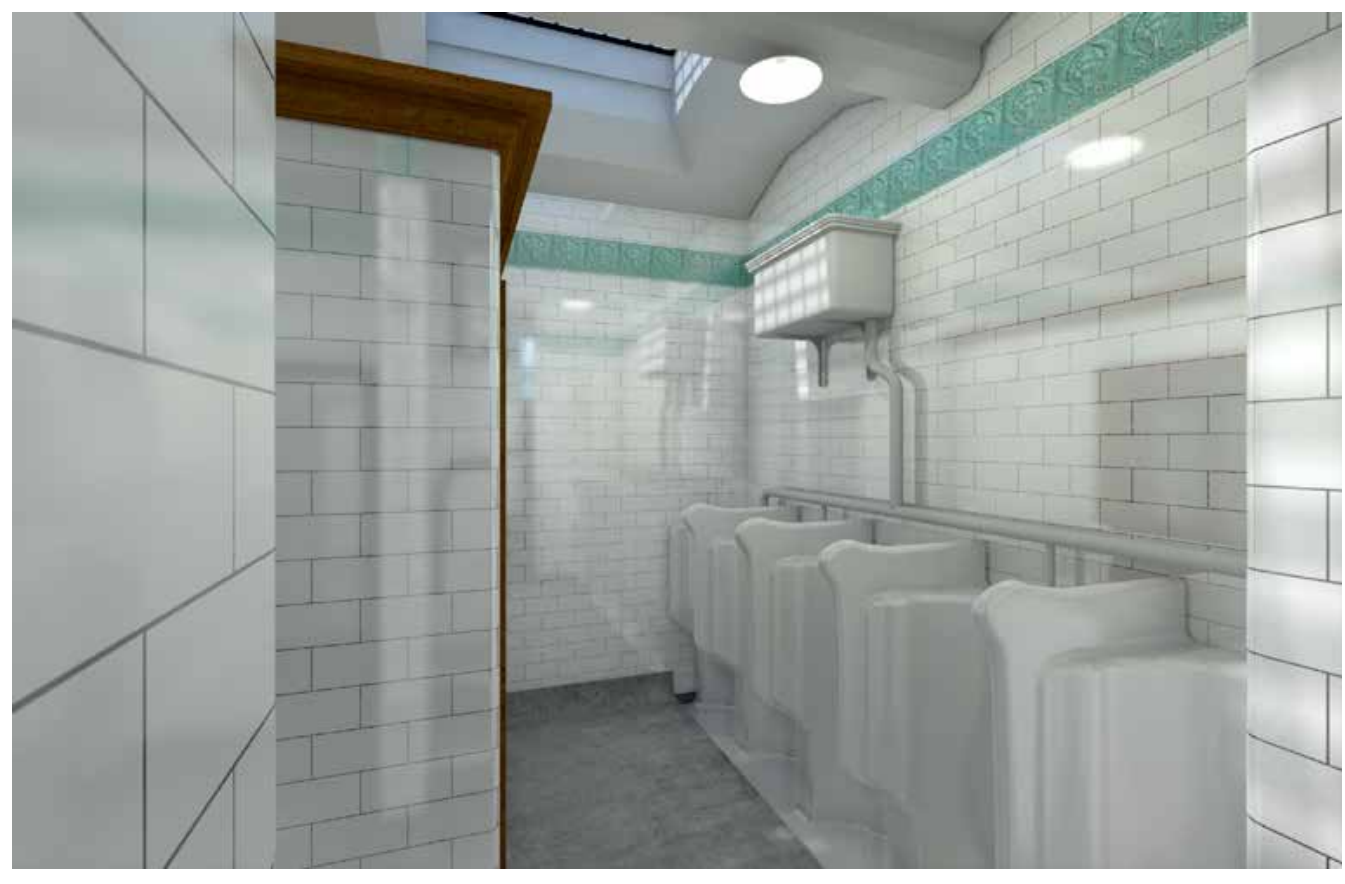

FIGURE 4. Virtual Rendering of the interior of Octagon Undergrounds created using original specifications and plans 1909, by Michael Findlay 2017 
built. The lavatory and attendants' areas were also enlarged ${ }^{42}$.

To help cover costs and generate income, Dunedin

followed the European practice of the "penny in the slot", to unlock the automatic locking system. The system was monitored by the attendants. Urinals were free. For a small installation cost, the locks raised substantial funds ${ }^{43}$. Within four weeks of opening, the two main undergrounds brought in an income of $£ 28$. This went some way to cover the running costs. The undergrounds were a significant financial commitment for a local authority and generating income ensured there were resources for ongoing maintenance and staffing.

The General Committee's statistical and financial information is fragmentary. There are no records contained in the archives other than opening income, and numbers that were recorded in the newspaper. Consistent reporting only began in 1916 within the Council's Annual Reports. Reports in the following years indicate that the Ladies conveniences in the Octagon were generating the most income - a logical finding given that water closets had to be paid for, while men could use the urinals for free.

Although the records are generally fragmented, for a short period the Dunedin City Council Annual Reports included the expenditure on all public conveniences in relation to the income the undergrounds were generating. As is evident in the table below, there was a significant gap between income and maintenance costs causing financial strain for the local authority.

\begin{tabular}{|c|c|c|}
\multicolumn{1}{c|}{ YEAR } & $\begin{array}{c}\text { INCOME FROM } \\
\text { UNDERGROUNDS }\end{array}$ & $\begin{array}{c}\text { EXPENDITURE ON ALL } \\
\text { PUBLIC FACILITIES }\end{array}$ \\
\hline $1917-18$ & $£ 45132$ & $£ 11616$ \\
\hline $1917-18$ & $£ 463711$ & $£ 119718$ \\
\hline $1917-18$ & $£ 659135$ & $£ 13201213$ \\
\hline
\end{tabular}

SOURCE. Dunedin City Council Departmental Reports, DCC Archives

ABOVE GROUND CONVENIENCES

While underground conveniences were being built, the Dunedin City Council also continued to build more above ground facilities to keep up with demand. The Manor Place conveniences built in 1912, were one such example. These conveniences still stand on the corner of Manor Place and

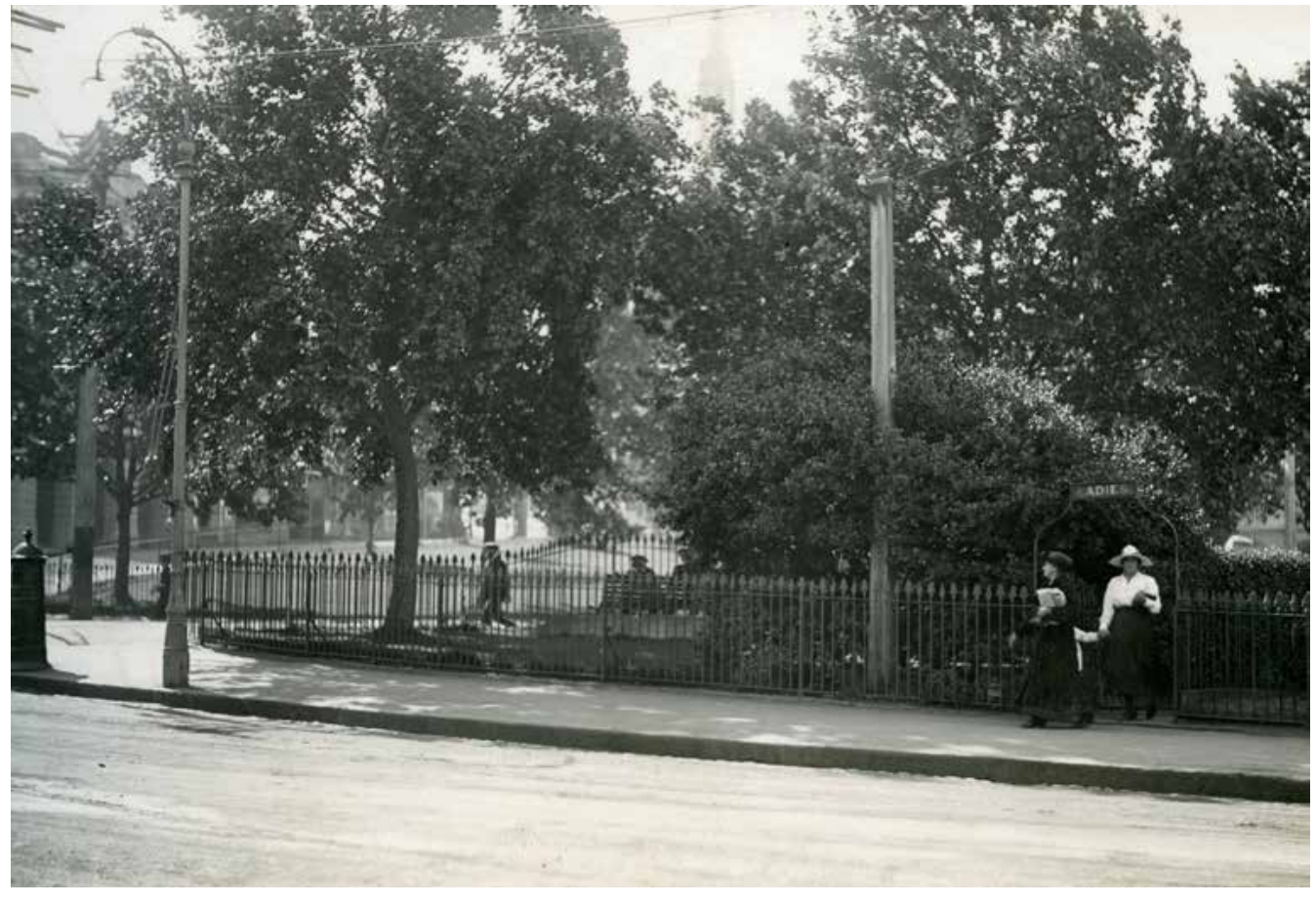

FIGURE 5. Octagon Underground Comfort Station, Ladies Entrance 1919, DCC Archives

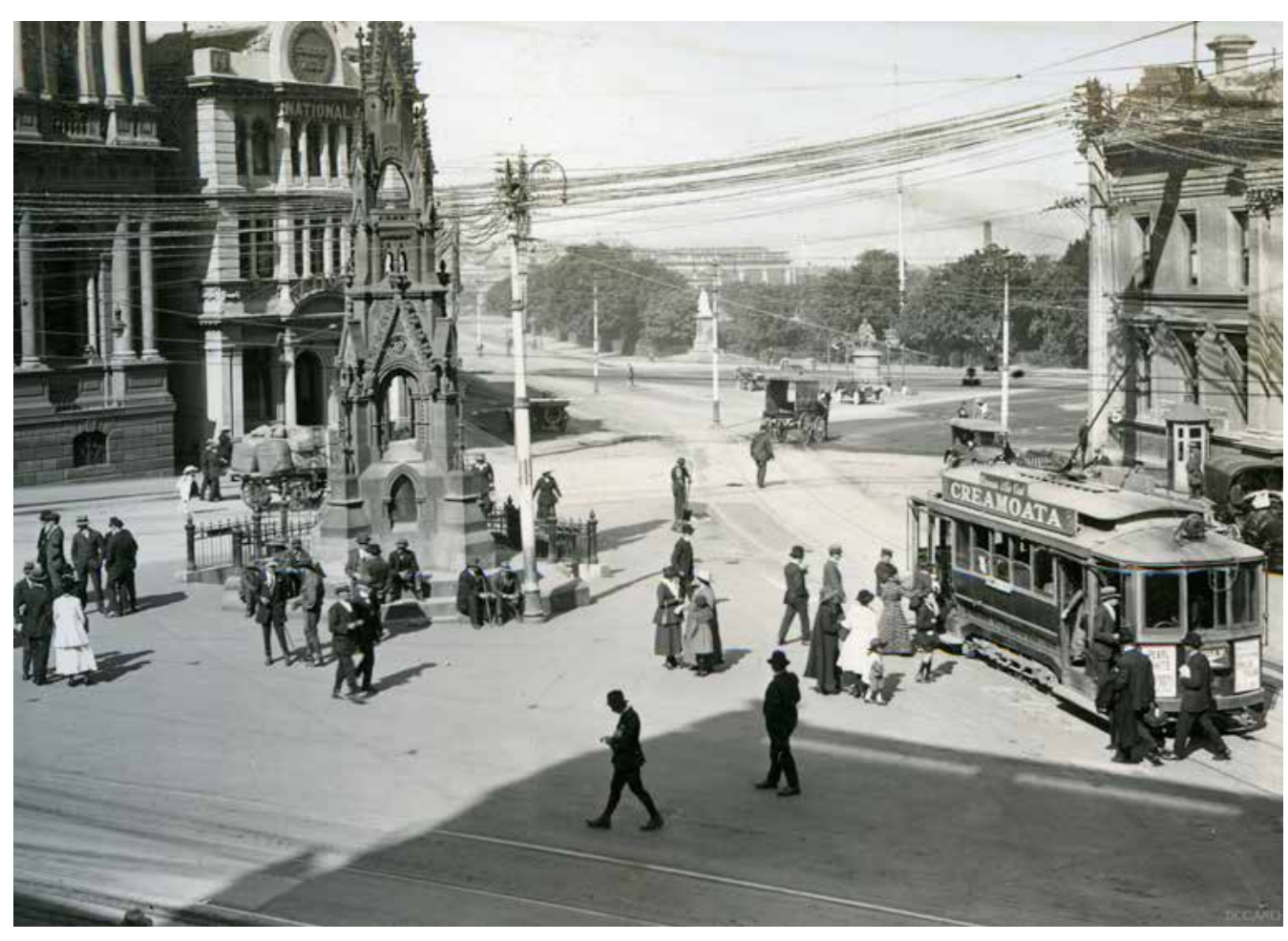

FIGURE 6. Custom House Square Underground Comfort Station, 1919, DCC Archives 
Princes Street. A structure with urinals had been on the site for many years, but in 1912 a petition signed by concerned neighbouring residents and ratepayers complained about the existing structure. They called for an underground convenience for both sexes, especially necessary for its proximity to two of the City Reserves and the proposed upgrade for the Oval Reserve ${ }^{4}$

The site was also the only public urinal between Jetty Street and Kensington. Chief Building Surveyor G.W. Gough agreed that a more modern structure could replace the old one. Using the special fund money allocated in 1909, the Council agreed to a new modern above ground convenience - for $\operatorname{men}^{45}$.

Mr A. Ferry won the contract to build the Manor Place convenience at a cost of $£ 295$, complete with Twyford's stoneware and the Twyford's Adament design ${ }^{46}$. The Manor Place urinals lined the exterior walls and formed the octagonal shape of the structure itself, mirroring the city's prominent landmark. Shrubbery was placed around the above ground station, to provide concealment for self-conscious patrons. The City Engineer later described the Manor Place structure as an "object of beauty, draped as it is in lovely native shrubs" 47 .

The local petitioners' concerns, however, were only partly addressed and there were ongoing fears that above ground facilities were detrimental to the areas in which they were situated. They may have been provided with a new modern convenience, but it was not underground - nor were any facilities supplied for women. The Council, for its part, had chosen the cheaper above ground structure as the special fund allocated only allowed limited works to be completed.

\section{THE ATTENDANTS}

It seemed the number of conveniences, especially those designed for women's use, would continue to be limited by the underground's significant drain on financial resources - for example, the need for attendants. Like other cities, Dunedin City Council employed attendants to run and maintain the underground conveniences. There were four male and two female attendants initially stationed in the Octagon conveniences and male attendants at the Custom House Square conveniences, who worked shift hours. Dunedin's other facilities had visiting attendants. Council decided that the attendants had to be old 'servants' of the Corporation or a widow of an ex-staff member of the Corporation ${ }^{48}$. The original job applications remain in the Dunedin City Council

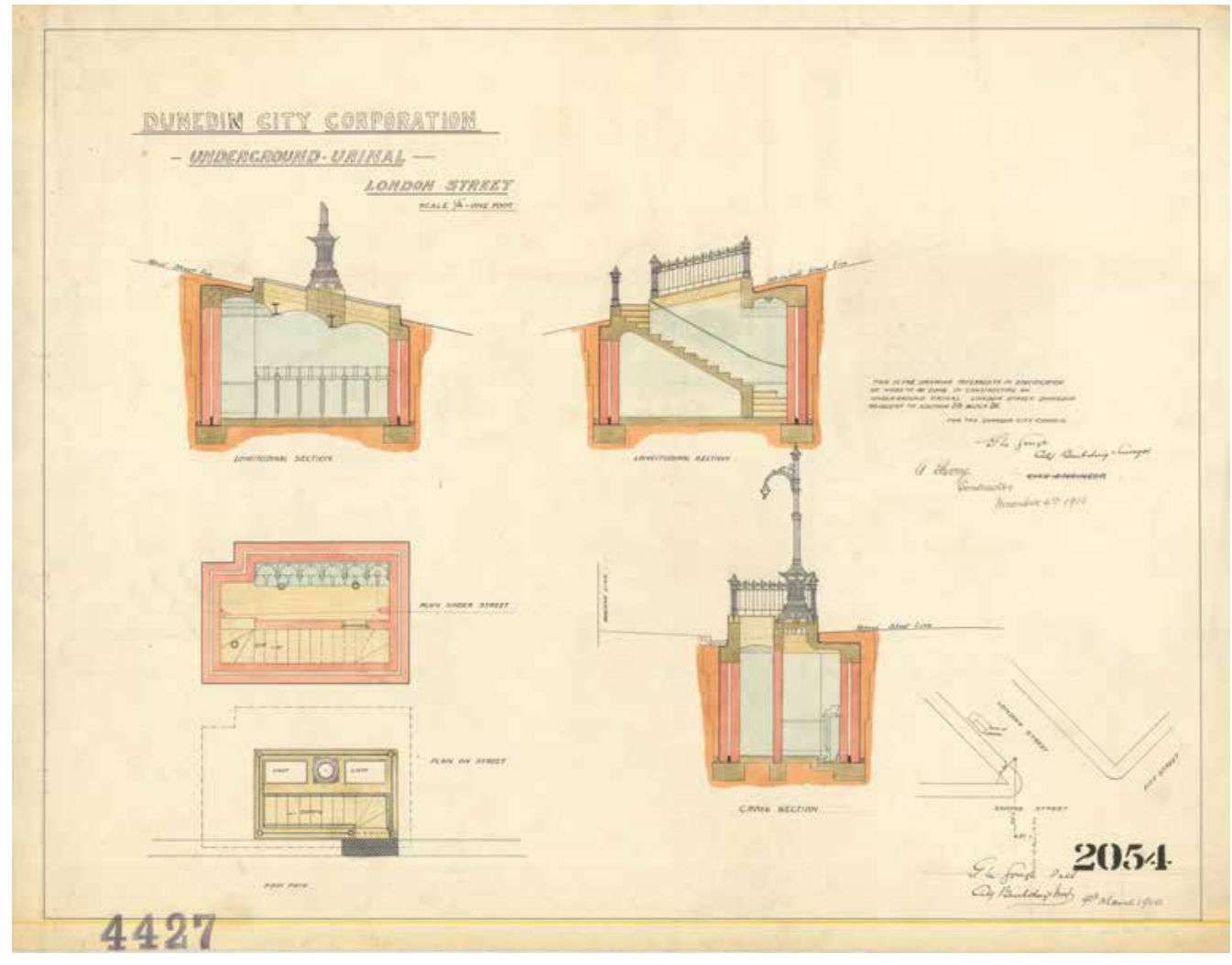

FIGURE 7. London Street Underground Conveniences,

Plan 4427, City Engineers 14/2/2ba

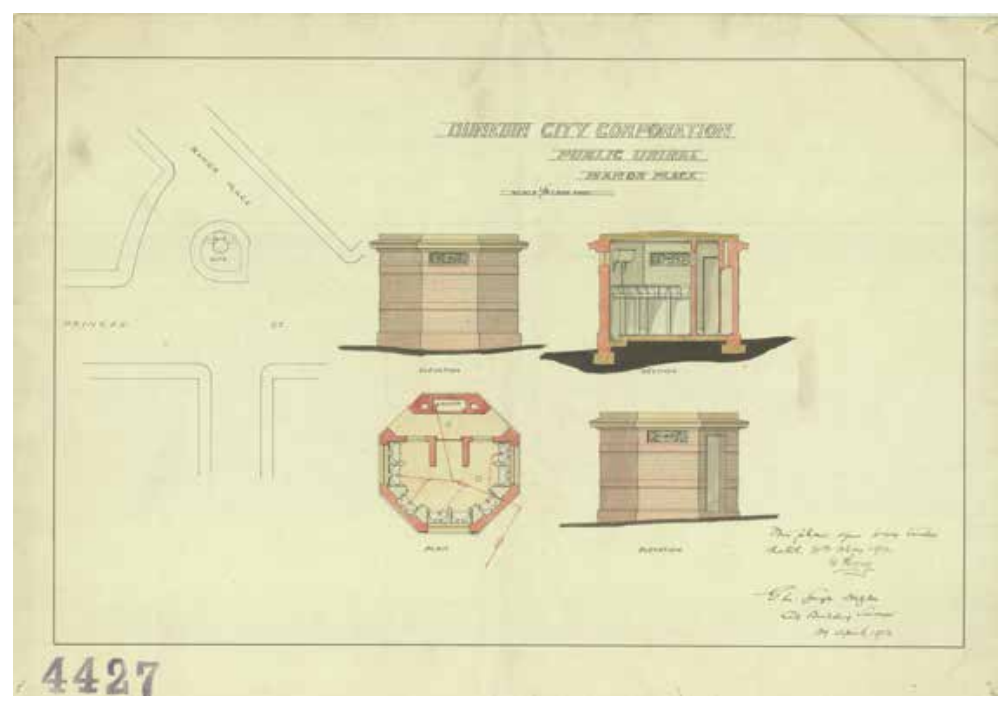

FIGURE 8. Manor Place Convenience Plans, 1912, DCC Archives, City Engineers 14/2/2/d 
The attendants were essential to keep the undergrounds in a hygienic state. They also managed behaviour and security within the subterranean spaces, which were prone to a certain degree of ill-mannered behaviour. Required to work eight hours a day, seven days a week they received 12 days leave a year on full pay. The attendant role was essentially "caretakers work and not arduous" reported the Town Clerk in $1912^{49}$. The role did come with issues and risks, however, as a City Engineers report noted in 1919:

Complaint has been made lately of a nuisance on the Station itself, thus: - When the closing hour for the adjacent pubs arrived gentlemen who have been undergoing bar treatment come out into the street. The treatment is said to effect [sic] their minds and paralyses their bodies to some extent. They fill up the underground place and are complained of as bringing in alcoholic pandemonium of vulgarity,

obscenity, and blasphemy to the loathing and disgust of the officer in charge, and all untreated persons within hearing. The paralysis of

the gastric nerves, due to the bar treatment, causes some to empty their stomachs about the place, but the mess is immediately cleaned up and no complaint comes from the surface ${ }^{50}$.

Incidents were also reported of attendants suffering assaults. In 1923, for example, the Council Minutes included a note that attendants had recently been assaulted in a "cowardly manner" 51 . The Council requested that the police make more regular and frequent visits to the undergrounds while on duty, particularly in the evening. The Custom House Square had problems with drunken crowds on Saturday nights and the police were often requested by Council to patrol these areas late at night. In 1939 recent special events had seen increased demand, especially by visitors to the city, and the Council decided that the Custom House Square conveniences be open all night. The convenience was without an attendant from 11pm and the Superintendent of Police intimated that his officers would visit the site regularly over those hours ${ }^{52}$
In the history of Dunedin's public conveniences, a lack of women's toilets was also an issue. "Country Mother" wrote in 1924:

“...why is there no restroom such as they have in other towns? As a visitor to your fair city on a public holiday, the only conveniences that I know about are at the railway station and the Octagon, and unlike the ever-fortunate male sex, the inevitable penny must be forthcoming for each and all. It is high time women were elected on the City Council, where their influence would enable free conveniences for women and children to be established in the town." 53

Dunedin did have women's conveniences, but they were few and far between. In 1908, the first Dunedin public toilets built for women were beside the tearooms at St Clair and were built a year before the underground conveniences in the city ${ }^{54}$. St Clair Beach was a popular family destination, especially once tram travel had become more common and was a "respectable" activity to enjoy with the family. Dunedin City Council took over the running of the conveniences in 1910. However, these were not a centralised city convenience, enabling women to spend extended time in the central business and retail districts of the city.

Department stores also provided conveniences for their customers - the more time customers spent at their stores, the more they spent. Large Dunedin companies including Brown and Ewing's, Drapery Supply Association, and Kirkpatrick and Glendining \& Co provided facilities for their female clientele. Although local Dunedin department stores such as these provided restrooms for women from the 1870 s, use of the facilities was still limited to those women who could afford to shop in these stores. The poorer underclass, who did not frequent larger stores, simply had no options. This limited women's ability to move freely in public spaces.

The public continued to voice their concern over what amounted to exclusion of women from these public spaces. Some were concerned that women visiting the city would not know which stores included restrooms ${ }^{55}$. Others observed that " $[\mathrm{m}]$ any other deficiencies mark Dunedin, and particularly so in regard to public conveniences for both sexes. This city is utterly lacking in even the most common conveniences in this respect" wrote "Ratepayer" in $1906^{56}$ 
Dunedin's women were not alone in suffering this indignity - the city was part of an international pattern which did not provide facilities for women. Various women's organisations in the Western world lobbied for access to public spaces, recognising the connection between access to public facilities for women and their place in wider society ${ }^{57}$. In England it was a main platform of the suffragette movement ${ }^{58}$. Although London had built the first underground conveniences in the world in 1855, it was another 40 years before women got their first conveniences, in the form of a dual-sex facility. In August 1893, the first convenience opened for women at Holborn. Sarah McCabe in her work on gender differentials in the provision of underground conveniences in London, noted that soon after Holborn's opening that it was extensively used by both males and females ${ }^{59}$.

The Commissioners of Sewers in the City of London went on to build five more underground conveniences the next year - all exclusively for male use.

As well as prevailing social attitudes preventing general acceptance of women in the public sphere, a more pressing issue for local authorities was the cost needed to build women's facilities. Providing water closets for women was more expensive than men's facilities. In an analysis into the London dual facility in 1895 , McCabe noted it cost $175 \%$ more to build than a men's-only convenience ${ }^{60}$. Undergrounds cost more to construct in any case, not only due to being subterranean but also due to the space that water closets and lavatories required. In contrast above ground urinals were inexpensive and could be erected for $£ 20$ each. The only benefit, from a local authority's perspective, was the ability to charge for the use of women's conveniences, generating income.

By 1927 the provision of conveniences for women in Dunedin was still woefully inadequate: "We find that the needs of our womenfolk are almost entirely ignored. The position is unjust, harmful, and a disgrace to the city. No time should be lost in having the matter remedied. Because the sex affected is not given to letter writing and is in main restrained by inherited feelings of false modesty - is no excuse whatever for the authorities not providing better or more numerous conveniences for women", writes a "Mere Man" in $1927^{61}$. The demand for more conveniences continued into the 1930s, albeit with a new challenge to authorities - women's conveniences should be free. "Surely our town could supply conveniences as freely for women and children as it does for men" wrote "A.F". "Why should even the rest rooms not be free, and why should it be necessary to ascend steep stairs to them - which elderly women and mothers with babies and small children find difficulty in climbing? ${ }^{62 "}$
Despite these ongoing demands, some improvements had been made. From the 1920s the Dunedin City Council delegated the running of new public women's rest rooms to the Ladies Advisory Committee. Restrooms became modern spaces that were more inclusive - they were easily accessible, preferably on a ground floor and provided wider services than just a basic water closet. This echoed the new wave of architecture that came to dominate in New Zealand. Drawing from the Arts and Crafts and bungalow styles of architecture, buildings took on a homelier appearance. This more relaxed, comfortable style was reflected in the new restrooms for women and ideas around public toilets for women, which were understandably more popular than the underground facilities provided by the Council ${ }^{63}$. The idea of 'rest' was linked to ideals of maternity, providing spaces for feeding and changing babies as well as creating a private space where women and children could rest within the public sphere ${ }^{64}$. As the table below shows, the use of the underground convenience in the Octagon began to fall after the mid-1920s.

\section{CONCLUSION}

Conveniences Income 1916-1950

SOURCE. Dunedin City Council Annual Reports

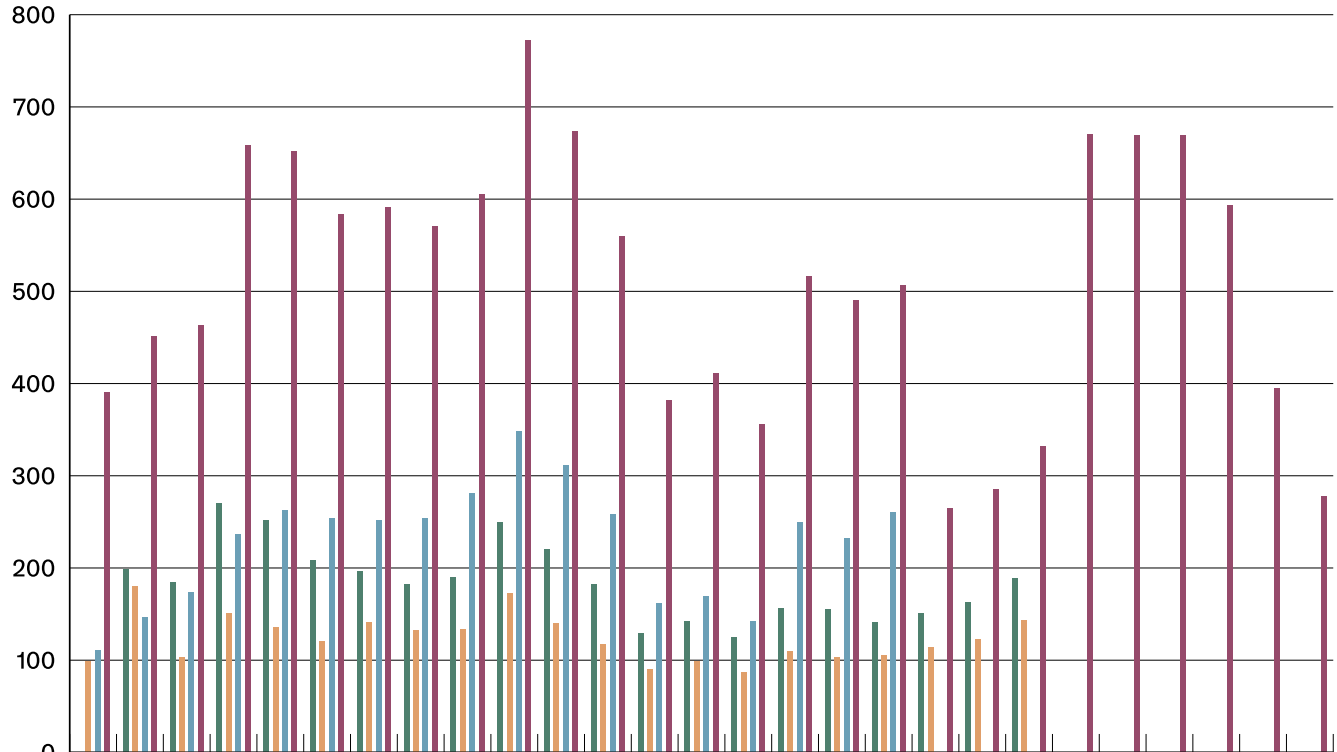

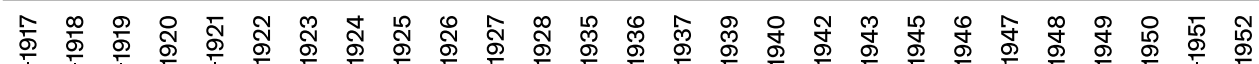

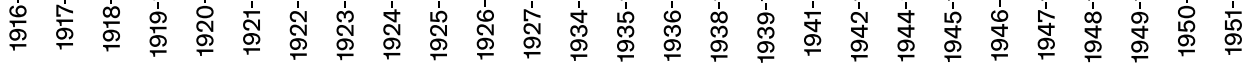

Customhouse Square Octagon (Men's) $\quad$ Octagon (Women's) Total 
The period between 1910, when the first underground conveniences were opened, and 1929 saw enormous transformations in the story of Dunedin's public toilets especially in their design, construction and visibility. A large investment was made by Dunedin City Council in establishing the underground conveniences and a long-awaited facility was also provided for women. Restrooms began to gain mo-

mentum in the city as the public demanded better facilities. While Council generally considered the supply of the public conveniences a success as demonstrated by usage statistics, there was a large cost in maintaining these facilities. As the public continued to demand more facilities, challenges such as increasing vandalism combined with high maintenance costs and the rise of the women's rest rooms, led to a demise of popularity of the underground conveniences over the next decades. By the mid-1960s, two out of the three conveniences had been demolished and replaced with cheaper, easier to clean stainless steel modern toilets. In 1989 the last Edwardian underground convenience was demolished in the Octagon; convenient no longer.

\section{REFERENCES}

City of Sydney Archives, n.d. "Sydney's Aldermen - Richard Watkins Richards, Richard Watkins Richards http:I/

Cooper, Annabel with Robin Law, Jane Malthus, and Pamela Wood, "Rooms of Their Own: Public Toilets and

Gendered Citizens in a New Zealand City, 1860-1940," 2000): 41 https://doi.org/10.1080/713668884, p. 418 .

Daley, Caroline. “Flushed with Pride? Women's Quest for Auckland, N.Z., Aut 2000; v.16 n.1:P.95-113; Issn:, 00:00 1300, 101, https://natlib.govt.nz/records/20643752.

Denley, James. “A History of Twyfords 1680 - 1982," Twyfords: Stoke-on-Trent, 1982.

Dunedin City Council Archives.“Town Clerk Correspondence (TC33), 1906, Public Works, L/1" (1906).

Dunedin City Council Archives."Public Works Committee Minutes, 4 July 1907, TC 4/1/13" (July 4, 1907).

Dunedin City Council Archives. “Municipal Reform Provision of Unde

Dunedin City Council Archives. "Municipal Reform - Provision of Underground Conveniences", Finance Committee, 1909

Dunedin City Council Archives."Town Clerk Series 33 Correspondence (TC33), 1910-1911, General U/1" (nd). Dunedin City Council Archives. "City Engineers Plan - Additions to Convenience, 1911, Plan 8925" (May 23, 1911). Dunedin City Council Town Clerk Series 33 Correspondence (TC33) 1912, General, U/1.

Dunedin City Council Archives."City Engineers Series Correspondence, Volume 18, 1919-1928" (1919).

Dunedin City Council Archives. "Dunedin City Council Minute Book, 1923, TC1/4, p 436" (1923).
Dunedin City Council, “Dunedin City Council Annual Report 1038-39" (nd) Dunedin City Council Archives.

Evening Star, July 5, 1907, Issue 12706.

Evening Star, July 18, 1907 "Public Health Matters," Issue

Evening Star, August 28, 1907, Issue 12752 .

Evening Star, September 12, 1907, Issue 12765

Evening Star, December 6, 1910.

Evening Star, May 30, 1927, “Public Conveniences" Issue 19569

Flanagan, Maureen. "Private Needs, Public Space: Public Toilets Provision in the Anglo-Atlantic Patriarchal City London, Dublin, Toronto and Chicago," Urban History 90, https://doi.org/10.1017/ S0963926813000266

Jordan, Kate. “Women's Rest Rooms James Lane, New Plymouth - Conservation Report," 2017.

McCabe, Sarah “The Provision of Underground Public ferentials, 1850s-1980"” (Masters, University of London, 2012), http://sas-space.sas.ac.uk/6093/.

Otago Daily Times, "Public Nuisances", March 14, 1900 Otago Daily Times, "Current Topics", April 23, 1906. Otago Daily Times, “A Deserving Cause", July 7, 1906, Issue 13639

Otago Daily Times, February 2, 1911, Issue 15057.

Wood, Pamela J. Dirt: Filth and Decay in a New World Arcadia, Auckland: Auckland University Press, 2005 
1. Pamela J. Wood, Dirt: Filth and Decay in a New World Arcadia Auckland: Auckland University Press, 2005, 132 2. The term 'conveniences' or 'comfort stations' were 'toilet' became in general use in New Zealand.

3. "Public Nuisances," Otago Daily Times, March 14,

4. "Current Topics," Otago Daily Times, April 23, 1906, Issue 13574 edifion, https://paperspast.natlib.gov..nz/ newspapers/ODT19060423.2.28? end_date $=31-12$ 1906\&items_per_page $=100 \&$ phrase $=2 \&$ query $=$ curent

5. “Town Clerk Correspondence (TC33), 1906, Public Works, L/1" (1906), Dunedin City Council Archives.

6. "Town Clerk Correspondence (TC33), 1906, Public Works, L/1."

7. Sarah McCabe, "The Provision of Underground Public Conveniences in London with Reference to Gender Dif(Merentials,

8. Annabel Cooper, Robin Law, Jane Malthus, and Pamela Wood, "Rooms of Their Own: Public Toilets and Gendered Citizens in a New Zealand City, 1860-1940," Gender, Place \& Culture 7, no. 4 (December 1, 2000): 41 https://doi.org/10.1080/713668884, page 418.

9. "Sydney's Aldermen - Richard Watkins Richards," Richard Watkins Richards (City of Sydney Archives, n.d.). ard-richards.

10. "Sydney's Aldermen - Richard Watkins Richards.

11. "Public Health Matters," Evening Star, July 18, 1907, (1.

ewspapers/ESD19070718.2.35.

13. "A Deserving Cause.," Otago Daily Times, July 7, 190 Issue 13639 edition, https://paperspast.natlib.govt.nz/ enrase $=28 q u e r y=a+d e s e r v i n g+c a u s e$ start_date $=01$ 01-1902\& title=ODT

14. The Evening Star, July 5, 1907, Issue 12706 edition, https://paperspast.natlib.govt.nz/newspapers/ ESD19070705.2.17?end_date $=05-07-1907$ iitems_per_ page $=100 \&$ phrase $=2 \&$ query $=$ voluminous + report \&sort

15. "Public Works Committee Minutes, 4 July 1907, TC 4/1/13" (July 4, 1907), Dunedin City Council Archives.

16. "Public Health Matters", Evening Star, July 18, 1907. 17. “Wednesday, August 28, 1907," Evening Star, Augus 28, 1907, Issue 12752 edition

8. “Evening Star," Evening Star, September 12, 1907, Issue 12765 edition.
19. "Municipal Reform - Provision of Underground nce Committee, 1909, Dunedin City

20. This money was the excess after using the accrued sinking fund remaining when the matured debentures had been paid off.

21. "Public Works Committee Minutes", Town Clerk Series, Dunedin City Council Archives, 4/1, 26 July 1900

22. Dunedin City Council, “Town Clerk Series 33 Correspondence (TC33), 1910-1911, General, U/1" (n.d.), Dunedin

23. Dunedin City Council.

24. Dunedin City Council.

25. James Denley, "A History of Twyfords 1680 - 1982," Twyfords: Stoke-on-Trent, 1982, p. 9

26. Denley, 41.

27. "City Engineer Contract File $3 / 3$, Contract 93 and 233 - Public Conveniences" (1910), Dunedin City Counc

28. "City Engineer Contract File 3/3, Contract 93 and "Public Conveniences.

29. Nigel Isaacs, 'Public Conveniences', BUILD, 98, (FebMarch 2007) 94-95.

30. "Town Clerk Series 33 Correspondence (TC33), 1919, General C/4 (n.d.), Dunedin City Council Archives. Town Clerk Series 33 Correspondence (TC33) 1912, General, U/1" (1912), Dunedin City Council Archives.

31. "City Engineer Contract File 3/3, Contract 93 and

"Public Conveniences"

32. Dunedin City Council, “Town Clerk Series 33 Correspondence (TC33) 1920, General, C/3" (n.d.), Dunedin City

33. "City Engineer Contract File 3/3, Contract 93 and 233 - Public Conveniences.'

34. Dunedin City Council, "Town Clerk Series 33 Correspondence (TC33), 1910-1911, General, U/1.

55. Caroline Daley, "Flushed with Pride? Women's Ques for Public Toilets in New Zealand," Women's Studies Journal, Auckland, N.Z., Aut 2000; v.16 n.1:P.95-1

36. “Dunedin City Council Minute Book" (1910), 455, TC124 , Dunedin City Council Archives

37. "City Engineer Contract File $3 / 3$, Contract 93 and 233 - Public Conveniences.'

38. "Evening Star," 25 August 1910 and "City Council" 8 November 1910

39. Dunedin City Council, "Dunedin City Council Minute Book, 1912, TC1/25," 665-66 TC1-24.
40. "City Council Reports," Evening Star, October 2 1910, Issue 14509 edition, https://paperspast.natlib.govt. D19101029.274.

11. "Otago Daily Times," Otago Daily Times, February 2 1911, Issue 15057 edition, https://paperspast.natlib.govt. nz/newspapers/ODT19110202.2.40.

42. "City Engineers Plan - Additions to Convenience, 1911, Plan 8925” (May 23, 1911), Dunedin City Council Archives, https://www.flickr.com/photos/ Qq-egQyFv.

43. Dunedin City Council, “Town Clerk Series 33 Correspondence (TC33), 1910-1911, General, U/1:

44. Dunedin City Council, “Town Clerk Series 33 Correspondence (TC33) 1912, General, U/1" Letter 1085

45. Dunedin City Council, "Dunedin City Council Minute

46. Dunedin City Council, "Town Clerk Series 33 Correspondence (TC33) 1912, General, U/1."

47. "City Engineers Series Correspondence, Volume 18, 1919-1928" (1919), Dunedin City Council Archives.

48. "Evening Star Column," Evening Star, December 6 ESD19101206.2.21.

49. Town Clerk Series 33 Correspondence (TC33) 1912 General, U/1, Dunedin City Council.

50. "City Engineers Series Correspondence, Volume 18 1919-1928" (1919), Dunedin City Council Archives.

51. "Dunedin City Council Minute Book, 1923, TC1/4, p 436" (1923), Dunedin City Council Archives.

52. Dunedin City Council, "Dunedin City Council Annua .

53. "City Utilities," Evening Star, October 8, 1924, Issue 18759. https://paperspast.natlib.govt.nz/newspapers/ ESD19241008.2.110.1.

54. Dunedin City Council, "Town Clerk Series 33 Correspondence (TC33) General, U/1, 1912 24 September Dunedin City Council Archives.

55. Pro Bono Publico, "Wanted, Public Conveniences for Both Sexes - To the Editor," Evening Star, July 5, 1906.

56. "The White Elephant," Otago Daily Times, August 4, nz/newspapers/ODT

57. Daley, "Flushed with Pride?" 96

58. Maureen Flanagan, "Private Needs, Public Space: Public Toilets Provision in the Anglo-Atlantic Patriarchal City: London, Dublin, Toronto and Chicago," Urban History
41, no. 02 (May 2014): 265-90, https://doi.org/10.1017/ S0963926813000266.
59. McCabe, "The Provision of Underground Public . 1850s-1980s," 33

60. McCabe, p.34.

61. "Public Conveniences," Evening Star, May 30, 1927 Issue 19569 edition, https://paperspast.natlib.govt.nz/ newspapers/ESD19270530.2.35.3.

62. "Public Conveniences," Otago Daily Times, April 29, . nz/newspapers/ODTh

63. Kate Jordan, “Women's Rest Rooms James Lane, .

64. Annabel Cooper, et al., "Rooms of Their Own: Public 1860-1940" Gender Place \& Culture 7, no 4 (December 2000): 428 